Article

\title{
Preliminary Study of the Potential Extracts from Selected Plants to Improve Surface Cleaning
}

\author{
Ai Ting Vong ${ }^{1}$, Hui Wen Chong ${ }^{2}$ (D) and Vuanghao Lim ${ }^{2, *}$ (D) \\ 1 Oncological and Radiological Sciences Cluster, Advanced Medical and Dental Institute, \\ Universiti Sains Malaysia, Bertam, Kepala Batas 13200, Penang, Malaysia; aitingv@gmail.com \\ 2 Integrative Medicine Cluster, Advanced Medical and Dental Institute, Universiti Sains Malaysia, Bertam, \\ Kepala Batas 13200, Penang, Malaysia; c_hwen91@hotmail.com \\ * Correspondence: vlim@usm.my; Tel.: +604-562-2427; Fax: +604-562-2349
}

Received: 5 December 2017; Accepted: 23 February 2018; Published: 6 March 2018

\begin{abstract}
Environment hygiene is important for preventing infection and promoting a healthier environment in which to live or work. The goal of this study was to examine the antimicrobial effects of Citrus aurantifolia (key lime) juice and aqueous extracts of Cinnamomum iners (cinnamon) bark and Citrus hystrix (kaffir lime) leaves on the kinetic growth of Pseudomonas aeruginosa and methicillin resistance Staphylococcus aureus (MRSA). Antimicrobial activity was quantitatively evaluated using spectrophotometry and viable cell counts versus bacterial growth time. The fomite surface samples that were used in the second experiment were chosen randomly from the laboratories. They were assessed both before and after intervention using a mixture of commercial disinfectant detergent and lime juice. In the kinetic growth study, the lime juice effectively eliminated P. aeruginosa and MRSA. The cinnamon bark extract was more effective at inhibiting P. aeruginosa than MRSA. The kaffir lime leaf extract demonstrated bacteriostatic activity for the first $60 \mathrm{~min}$, which then weakened after $90 \mathrm{~min}$ for both bacteria. The lime juice extract and commercial disinfectant mixture effectively disinfected the fomites. Further studies of the use of key lime juice as a disinfectant in the hospital environment should be conducted, as C. aurantifolia exhibits antibacterial activities against endemic microbes.
\end{abstract}

Keywords: antimicrobial; Cinnamomum iners; Citrus hystrix; Citrus aurantifolia; aqueous extract

\section{Introduction}

Indoor cleanliness should be maintained to a standard level to preclude surface degradation and to control the potential risk of infection and dust exposure. Environment surfaces, such as floors and tiles, are often covered by a layer of dust consisting of minerals, metals, fibres, particles, organic compounds, polycyclic aromatic compounds, and biological entities, including bacteria, pollen, and animal allergens. Disinfection via chemical or thermal action is essential in the cleaning process that provides broad microbiological sterilisation. Chemical disinfection is often the preferred choice for disinfecting and maintaining fomite surfaces [1]. The degree of bactericidal action against microorganisms depends on their sensitivity to the disinfectant chemical. A high level disinfectant helps eliminate microorganisms, excluding large quantities of spores, whereas low level disinfection is inefficient for mycobacteria or spore clearance [2].

A variety of cleaning agents have been formulated to aid in dust and dirt removal, disinfection, and surface maintenance [3]. The cleaning process involves chemical reactions, whereby deposits of minerals or inorganic salts are dissolved via acid-base reactions or complex formation or formation of micelles to remove dirt or lipid components [3]. The process also can reduce the microorganism load on the surface. The three types of cleaning are use of detergents, disinfectants, or the combination of the two. Detergents are effective at removing organic material and suspended grease or oil, whereas 
disinfectants can reduce or eliminate microorganisms. Detergent-disinfectants are capable of both functions [2], and the combination helps decrease the microorganism load significantly and quickly.

A wide spectrum of exposure to chemical agents can cause severe health problem, such as allergies, eczema, and asthma. Allergic response can be activated via skin contact or inhalation even if only small amounts of allergen are present in a disinfectant [3,4]. Exposure to chemical agents depends greatly on the quantity of residues, degree of off-gassing, and the amount of dissolved surface elements [3]. As disinfectant-detergents are formulated in concentrated solution and often in aerosol form, users should wear gloves when handling. Due to the potential health risks posed by chemical agents, alternative surface cleaning agents are needed. The goal of this study was to evaluate the potential for Citrus aurantifolia (key lime) juice and aqueous extracts of Cinnamomum iners (cinnamon) bark and Citrus hystrix (kaffir lime) leaves to eliminate bacteria effectively from surfaces.

\section{Results}

\subsection{Preliminary Screening of Plants Extracts}

The bacteriostatic effects of key lime juice and aqueous extracts of cinnamon bark and kaffir lime leaves on $10^{3}$ cells $/ \mathrm{mL}$ Pseudomonas aeruginosa and methicillin resistance Staphylococcus aureus (MRSA) were determined using a spectrophotometer (for optical density (OD) values) and the standard method of viable counts on agar as a reference. The P. aeruginosa positive control exhibited a smooth increase in the graph pattern for both OD and viable counts, which shows kinetic growth of healthy bacteria cells (Figure 1). Microorganisms were incubated with agitation in order to mix and enhance the growth of the bacteria. This helped to prevent cells from forming biofilms and aggregates. Bacterial growth increases with time until it reaches a plateau, indicating the cessation of bacterial growth due to nutrient depletion.

OD values for the cinnamon aqueous extract showed a sharp decrease over time, which was also apparent in the viable count data $\left(10^{3} \mathrm{CFU} / \mathrm{mL}\right)$ (Figure 1c,d). P. aeruginosa was susceptible to cinnamon at $90 \mathrm{~min}$, at which time a negative OD value was detected and no viable cells were counted. The decrease in OD represented the death phase of P. aeruginosa. Both methods reflected a correlation in sustaining the sensitivity range of the P. aeruginosa with a constant concentration of the extracts sufficient for inhibiting bacteria in standardised turbidity of cell suspension. The kaffir lime aqueous extract treatment showed a smooth decline in absorbance over time, with a slight increase at $90 \mathrm{~min}$. This pattern reflected the viable count result (Figure 1e,f). Inhibition of P. aeruginosa occurred between 0 to $60 \mathrm{~min}$, which means that the kaffir lime aqueous extract had a bacteriostatic effect in this time range, but the effect weakened by $90 \mathrm{~min}$. Lime juice had excellent bactericidal activity against $P$. aeruginosa, as indicated by the constant decrease in absorbance and the elimination of viable counts at the end of the experiment (Figure 1g,h).

The MRSA OD values of the positive control increased linearly, and the viable count values showed a slow increase (Figure 2a,b). OD and the viable cell counts of MRSA cells exposed to the cinnamon aqueous extract exhibited a constant decline (Figure 2c,d). OD and viable cell counts of MRSA cells that were exposed to the kaffir lime aqueous extract decreased at first and then increased at $90 \mathrm{~min}$ (Figure 2e,f). Thus, this extract had a bacteriostatic effect for the first $60 \mathrm{~min}$, but the effect weakened thereafter. MRSA cells that were exposed to lime juice showed a sharp decline in OD values and viable cell counts over the duration of the experiment (Figure 2g,h). 
(a)

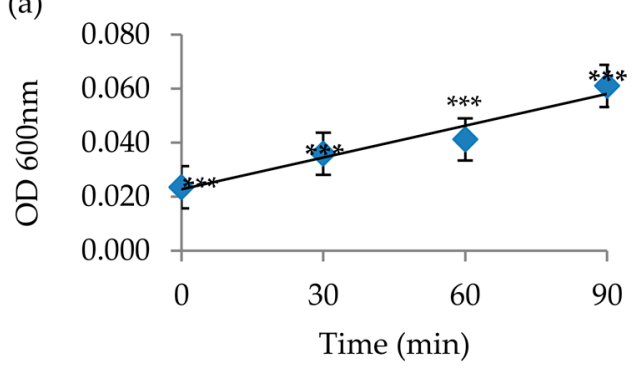

(c)

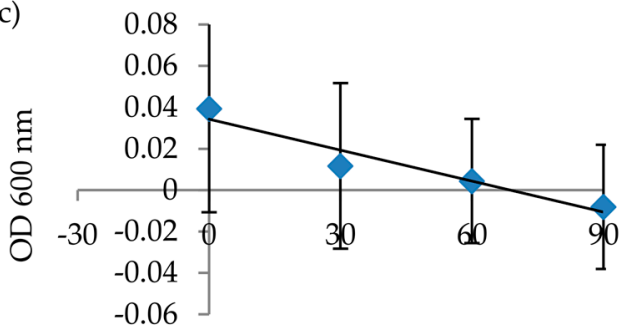

Time (min)

(e)

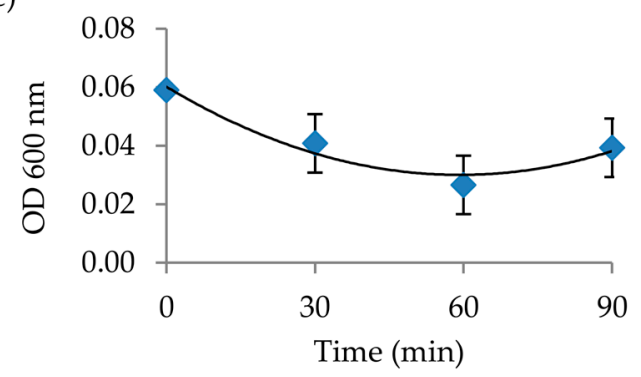

(g)

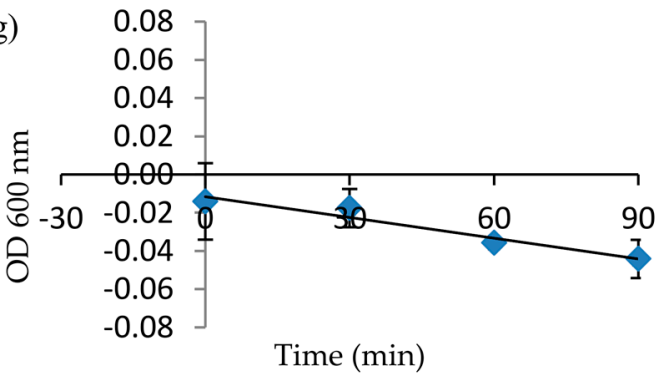

(b)

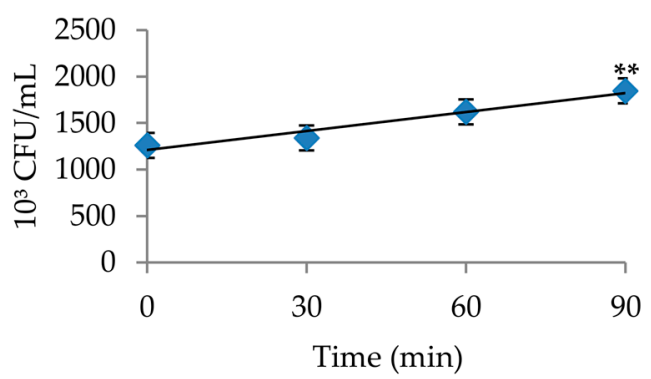

(d)

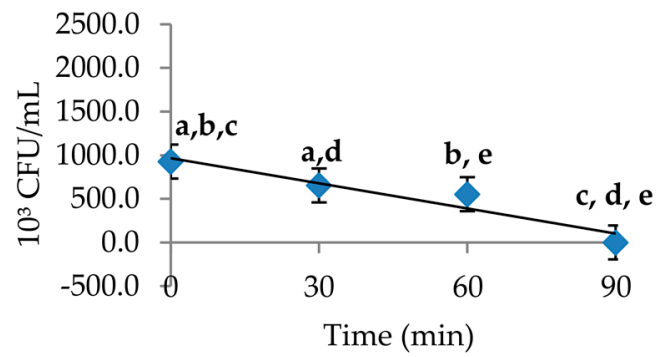

(f)

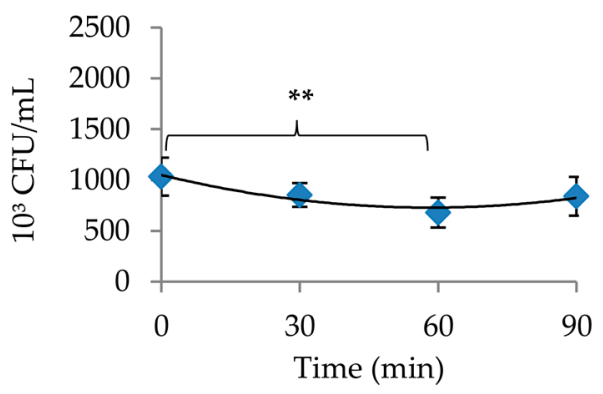

(h)

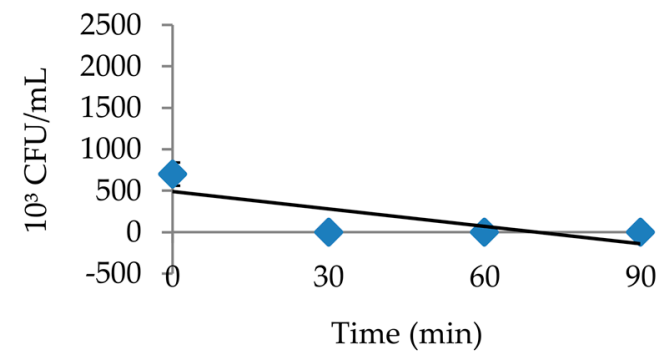

Figure 1. P. aeruginosa growth curve for the susceptibility test after exposure to $0.4 \mathrm{~g} / \mathrm{mL}$ of extracts from 0 to 90 min. (a) control optical density (OD) values, (b) control viable count values, (c) cinnamon aqueous extract $\mathrm{OD}$ values, (d) cinnamon aqueous extract viable count values, (e) kaffir lime aqueous extract OD values, (f) kaffir lime aqueous extract viable count values, (g) lime juice OD values, and (h) lime juice viable count values. The post hoc Tukey HSD test showed that the control OD values were very significantly different from each other at all time points (*** $p<0.00)$, whereas the control viable count value at 90 min was significantly different from values at all other time points $\left.{ }^{* *} p<0.01\right)$. The viable cell counts of $P$. aeruginosa exposed to the cinnamon aqueous extract differed significantly from each other at all time point (dots with same letter differ significantly, ${ }^{* *} p<0.01$ ), except for time points between $30 \mathrm{~min}$ and $60 \mathrm{~min}$. For the kaffir lime aqueous extract, viable count values at $0 \mathrm{~min}$ differed significantly from those at $60 \mathrm{~min}\left({ }^{* *} p<0.01\right)$. Results were expressed in OD $(600 \mathrm{~nm})$ and $10^{3} \mathrm{CFU} / \mathrm{mL}$, respectively, with $n=3$. 
(a)

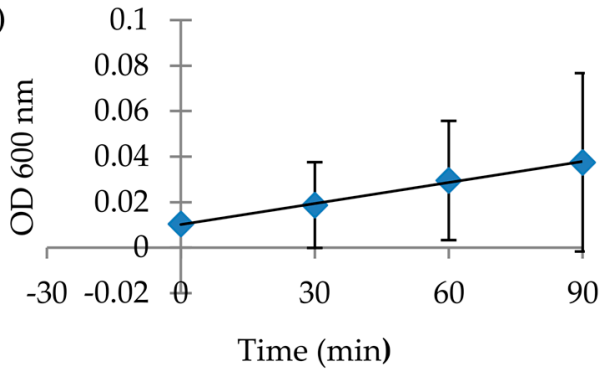

(c)

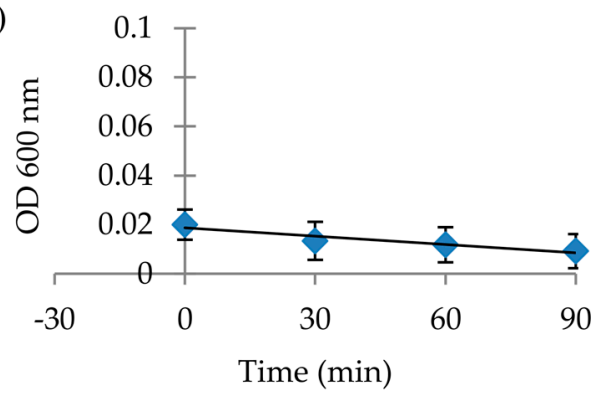

(e)

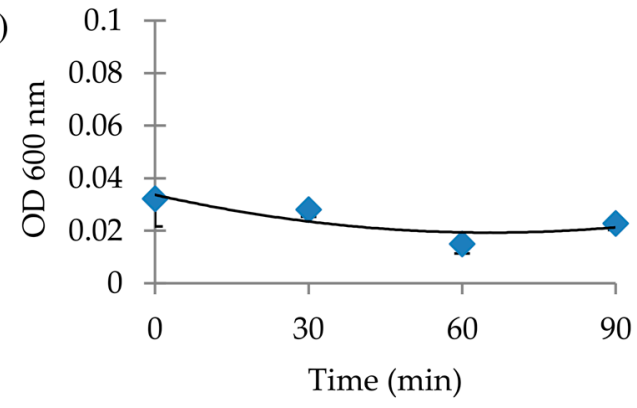

(g)

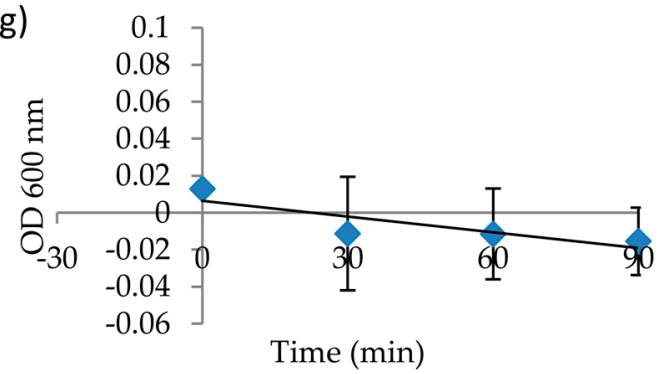

(b) 2500

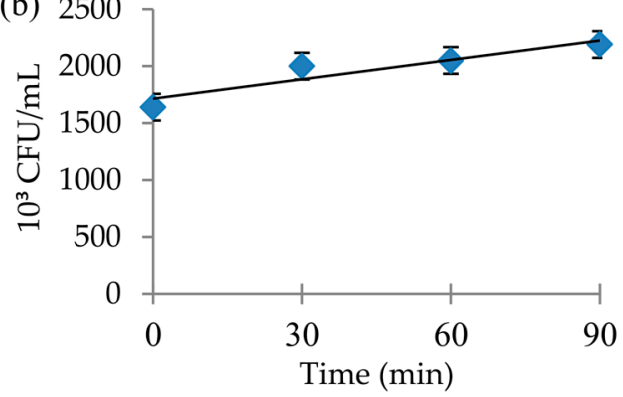

(d)
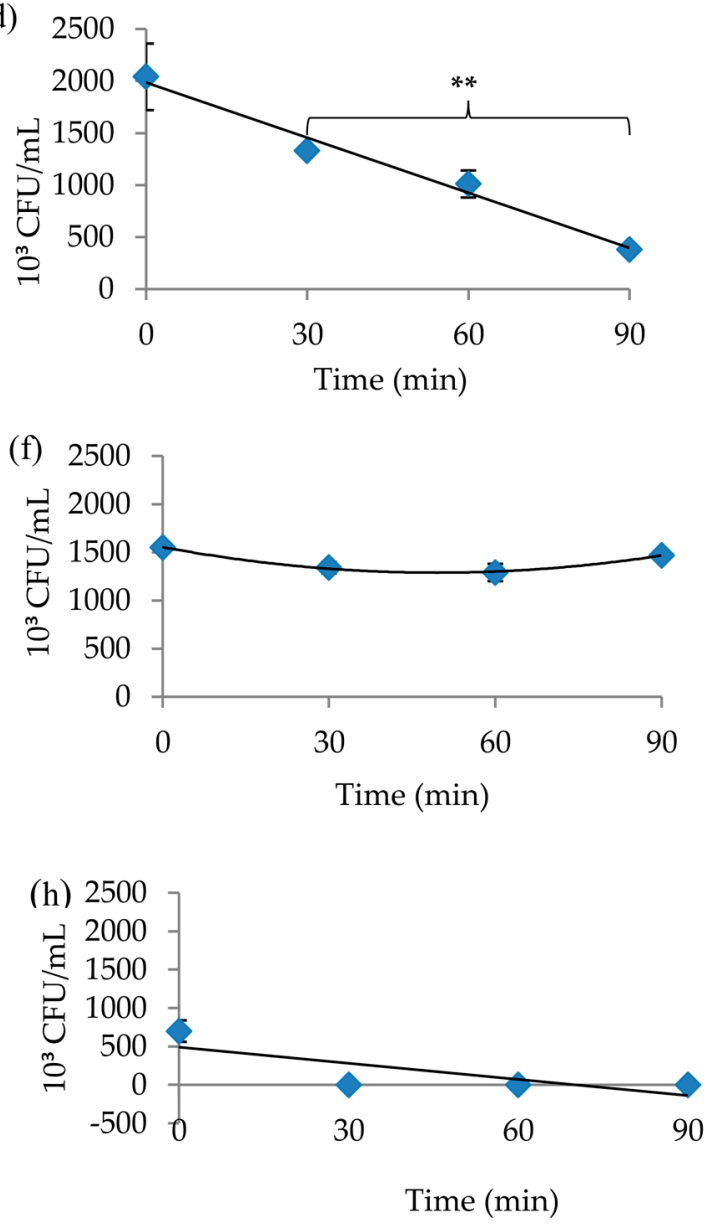

Figure 2. Growth curve of methicillin resistant Staphylococcus aureus (MRSA) for the susceptibility test after exposure to $0.4 \mathrm{~g} / \mathrm{mL}$ of extract from 0 to $90 \mathrm{~min}$. (a) control OD values, (b) control viable count values, (c) cinnamon aqueous extract OD values, (d) cinnamon aqueous extract viable count values, (e) kaffir lime aqueous extract OD values, (f) kaffir lime aqueous extract viable count values, (g) lime juice OD values, and (h) lime juice viable count values. The Dunnett T3 test indicated that the viable count values for the cinnamon aqueous extract at $30 \mathrm{~min}$ and $90 \mathrm{~min}$ differed significantly from each other $\left.{ }^{* *} p<0.01\right)$. Results were expressed in OD $(600 \mathrm{~nm})$ and $10^{3} \mathrm{CFU} / \mathrm{mL}$, respectively, with $n=2$.

\subsection{Preliminary Studies of Extracts as Potential Cleaning Agents}

Table 1 shows that the total clearance percentage of bacteria for lime juice was $86.7 \%$ for 15 sampled surfaces using the TSA contact agar plate, and this value was marginally higher than that of detergent (80\%). For detergent, 1 of $15(6.7 \%)$ sampled surfaces showed reduction of bacteria. 
The proportion of sample surfaces with no bacterial colonies for both detergent and lime juice was $13.3 \%$. Lime juice produced a better clearance rate than the commercial disinfectant detergent, which shows that $C$. aurantifolia juice is a competent cleaning agent.

The Gram stain analysis results (Table 2) demonstrated that the sanitation of the laboratories before intervention was in the marginal category, as Gram negative rod bacteria were not present in those laboratories. However, there were several gram positive cocci and rod bacteria that were found inhabiting in the environment of the laboratories. Most samples reached excellent sanitation after intervention, and only one fall under marginal sanitation due to the presence of gram positive rod identified to be Bacillus spp., a facultative anaerobe bacterium.

Table 1. Effectiveness of commercial disinfectant detergent and C. aurantifolia juice (\%) as cleaning agents.

\begin{tabular}{ccccc}
\hline & Null (\%) & Reduction (\%) & Clearance (\%) & Total \\
\hline Disinfectant detergent $(n=15)$ & 13.3 & 6.7 & 80.0 & 100 \\
\hline C. aurantifolia juice $(n=15)$ & 13.3 & - & 86.7 & 100 \\
\hline
\end{tabular}

Table 2. Gram stain test to determine the presence of Gram positive bacteria and Gram negative bacteria on the experimental surface.

\begin{tabular}{cccccc}
\hline \multicolumn{2}{c}{ Excellent Sanitation } & \multicolumn{2}{c}{ Marginal Sanitation } & \multicolumn{2}{c}{ Unsatisfactory Sanitation } \\
\hline Before & After & Before & After & Before & After \\
\hline$n=30$ & $n=30$ & $n=30$ & $n=30$ & $n=30$ & $n=30$ \\
4 & 29 & 26 & 1 & 0 & 0 \\
\hline
\end{tabular}

\section{Discussion}

In the control treatment, both $P$. aeruginosa and MRSA exhibited healthy growth, indicating that the environmental requirements for growth had been met in the experiment. Of the extracts that were tested, $P$. aeruginosa and MRSA were most sensitive to lime juice, followed by the cinnamon aqueous extract and the kaffir lime aqueous extract. Lime juice exhibited excellent bactericidal activity against P. aeruginosa throughout the duration of the experiment, and MRSA was susceptible to lime juice after $30 \mathrm{~min}$ (i.e., no growth in the viable count analysis). The cinnamon aqueous extract had a bacteriostatic effect for the first $60 \mathrm{~min}$ of the experiment and successfully eliminated P. aeruginosa for the subsequent time based on results of the count analysis. MRSA was sensitive to the cinnamon extract, as decreasing growth and variable count values were observed. Cinnamon exhibited better antimicrobial activity against $P$. aeruginosa when compared to MRSA. P. aeruginosa and MRSA were susceptible to the kaffir lime extract for the first $60 \mathrm{~min}$ of the experiment, but the bacteriostatic effect weakened by $90 \mathrm{~min}$, as shown by elevated growth rates. Both types of bacteria might have developed a special metabolic response to overcome and resist the kaffir lime extract after exposure to it for a period of time [5].

The spectrophotometric method is essential for obtaining total cell mass data from turbidity measurements. Cell mass is proportional to the number of cells. Sensitivity of spectrophotometry analysis is optimal at shorter wavelength, whereas longer wavelength is best for cell density measurement [6]. Moreover, because each bacterium has a different mass, the OD reading varies among different bacteria species. Future studies should focus on developing a technique to identify the OD that is most suitable for each bacteria type. Herein, P. aeruginosa had a higher OD reading when compared to MRSA, possibly because of the former's better proliferation rate. P. aeruginosa proliferates better in humid conditions, whereas MRSA multiplies better at lower humidity [7]. A negative OD value indicates that bacterial cytoplasmic membranes have collapsed and lysed due to the addition of bactericidal agents, such as citrus and cinnamon [6]. In the current study, the OD dropped dramatically when cells were exposed to lime juice. 
TSA contact agar plates are used for the isolation and cultivation of microorganisms [8]. However, some types of fastidious microorganisms, viruses, and fungi are not detectable using this method. A specific medium and factors (e.g., temperature) are needed to enhance growth of such species $[6,8]$. Therefore, the absence of microbial colonies before intervention is not necessarily a true negative result. The presence of Gram negative rod bacteria is indicative of poor sanitation and a very unhealthy environment in which to live and work. In this study, most of the samples from the three laboratories tested fell into the marginal sanitation category prior to intervention. This finding indicates that those laboratories were free of Gram negative bacteria, which are the main pathogenic agents that are responsible for causing disease, such as bacteraemia and NI associated infection [6].

After the disinfection treatment, one sample was in the marginal sanitation category. Gram positive rod bacteria were found on this surface in countable numbers after the disinfectant treatment, perhaps because this was a heavily used surface that likely contained organic matter, such as carbon, that contributed to the growth of bacteria [6]. Additionally, different microorganisms have different adhesion properties, which can switch between being reversible and irreversible. Bacterial strains that do not have slimy properties and have reversible adhesion are less likely to be pathogenic. Bacteria are less able to adhere to smoother surfaces, such as glass, as compared to plastic surfaces. Irreversible adhesion occurs during the first stage of biofilm (slime) formation. Bacteria can replicate inside biofilms, causing biofilm mass to increase. Biofilm formation depends on parameters, such as humidity and temperature [9]. The presence of biofilms makes the cleaning process difficult. If the surface is unhygienic and organic material is present (i.e., fuel for microorganisms), bacteria will accumulate on the surface and proliferate. Thus, before using disinfectant, it is advisable to wash and clean the surface to remove dirt [9].

The disinfectant detergent that was used in this experiment is capable of both cleaning and disinfecting. However, its use has side effects, such as allergies, eczema, and asthma [3,4]. Lime juice was previously shown to have antimicrobial activities due to the presence of bioactive compounds, such as phenolics, which can inhibit the growth of most food-borne and food spoilage microorganisms [10] via compounds that induce enzyme detoxification and regulate the immune response [11]. The results reported herein show that lime juice has bactericidal activities and can productively remove microorganisms from fomite surfaces. Further studies should focus on identifying the bioactive compounds present in lime juice and their potential for use in chemical and pharmacological applications [12].

\section{Materials and Methods}

\subsection{Plant Materials}

C. iners bark, C. aurantifolia fruits, and C. hystrix leaves were collected from Bertam, Kepala Batas, Malaysia. The plants were authenticated by a taxonomist, and voucher specimens were deposited in the Integrative Medicine Cluster Herbarium Collection.

\subsection{Aqueous and Juice Extraction}

For bark and leaf samples, one part dried plant $(20 \mathrm{~g})$ in five parts of sterilized water $(50 \mathrm{~mL})$ was boiled and reduced to one-fifth of the original volume. The mixture was autoclaved at $100{ }^{\circ} \mathrm{C}$ for $15 \mathrm{~min}$ for sterilisation [13]. C. aurantifolia fruits were wiped clean with $70 \%$ ethanol and distilled water. The fruits were cut in half with a sterilised knife and aseptically squeezed into a sterile beaker. The extracts and juice were centrifuged at $3500 \times \mathrm{g}$ for $20 \mathrm{~min}$ to remove undesired residue. Supernatant was collected and stored at $-20^{\circ} \mathrm{C}$ until used in the experiments $[12,14,15]$.

\subsection{Bacteria Susceptibility Test}

The two strains of bacteria used in this study were obtained from the American Type Culture Collection (ATCC) [16]. P. aeruginosa (ATCC 27853) and methicillin resistant Staphylococcus aureus 
(MRSA, ATCC 33591) were kept in the microbiology laboratory of the Clinical Trial Centre, Advanced Medical and Dental Institute (AMDI), Universiti Sains Malaysia (USM). Colonies were inoculated into the nutrient broth using a sterilised loop. The broth was mixed thoroughly using a vortex to prevent aggregation, followed by incubation overnight at $37^{\circ} \mathrm{C}$ in an incubator shaker [17]. Each cultured bacteria suspension was diluted via 10-fold serial dilution. For each species, a dilution of $10^{3}$ cells $/ \mathrm{mL}$ was prepared for the control and test samples. Cinnamon and kaffir lime aqueous extracts at $0.4 \mathrm{~g} / \mathrm{mL}$ and lime juice were evaluated in the susceptibility test using a quantity of $2 \mathrm{~mL}$ [18]. Control and test cultures were incubated with agitation at $37^{\circ} \mathrm{C}$. Absorbance was measured using a UV-VIS spectrophotometer (Perkin Elmer, Lambda 25, Norwalk, CT, USA), and a $50 \mu \mathrm{L}$ aliquot of each suspension was aseptically plated onto an agar plate to obtain viable counts. OD readings and plating analysis were conducted at $0,30,60$, and $90 \mathrm{~min}[17,19]$.

\subsection{Fomite Surface Sampling and Gram Staining}

Five surfaces of inanimate objects were randomly selected from the laboratories and marked [20]. The test surface was moistened with distilled water to facilitate the dispersion of bacterial clumps and result in a higher count. Moreover, a dry surface could it make difficult to transfer bacteria to the agar due to surface charge, topography, and hydrophobicity [21]. The control treatment contained only distilled water and was sprayed on the test surface and left for $5 \mathrm{~min}$ before sampling. A similar procedure was utilised for the test treatment, which consisted of disinfectant detergent and lime juice. After spraying the surface with the control or test treatment and allowing it to sit for $5 \mathrm{~min}$, the test surface was wiped and cleaned with distilled water. An agar plate was applied to the surface for $5 \mathrm{~s}$ and then incubated at $35{ }^{\circ} \mathrm{C}$ for $24 \mathrm{~h}$ [21,22]. The number of colony forming units (CFU) per area sampled $=\mathrm{CFU} / \mathrm{cm}^{2}$ was calculated to determine $\%$ effectiveness. The $\%$ effectiveness before (control) and after disinfection was calculated using the following formula [23]:

$$
\frac{\text { Before / after test }\left(\mathrm{CFU} / \mathrm{cm}^{2}\right)}{\text { Total before/after test }\left(\mathrm{CFU} / \mathrm{cm}^{2}\right)} \times 100 \%
$$

To examine the contents of the agar plates, a colony from a given sample was smeared onto a glass slide and dried near a flame. The slide was flooded with crystal violet solution for $1 \mathrm{~min}$ and rinsed with tap water for $2 \mathrm{~s}$. The slide then was flooded with Gram's Iodine solution (mordant) and alcohol to decolourise the sample. Safranin solution (counterstain) was added and rinsed with water after $30 \mathrm{~s}$. The slide was allowed to dry on a slide warmer and then examined under an oil-immersed microscope $(1000 \times)$ [24].

\subsection{Statistical Analysis}

Data were analysed using Statistical Package for the Social Sciences (IBM SPSS version 22.0, Armonk, NY, USA). One way ANOVA Dunnett T3 test and post hoc Tukey HSD test were used to determine the significance of samples at different time point where ${ }^{* *} p<0.01 ;{ }^{* *} p<0.00$.

\section{Conclusions}

C. aurantifolia juice is a potential bactericidal agent that exhibits strong and effective bactericidal activity against $P$. aeruginosa and MRSA and is not affected by organic material. Thus, lime juice could be used as an effective disinfectant. Future studies of its use in cleaning intervention should include sampling from clinics and hospitals and different types of surfaces. Domestic household and hospital employees could benefit from development of a cleaning product containing $C$. aurantifolia juice.

Acknowledgments: This study was financially supported by an APEX Delivering Excellence 2012 Grant (DE 2012, 1002/CIPPT/910325) and the AMDI Student Incentive Fund, Universiti Sains Malaysia (USM), Penang, Malaysia. The authors thank USM for a fellowship that provided financial support for student H.W.C. 
Author Contributions: V.L. conceived and designed the experiments; A.T.V. performed the experiments; V.L., A.T.V. and H.W.C. analysed the data; H.W.C. wrote the paper.

Conflicts of Interest: The authors declare no conflict of interest.

\section{References}

1. Rutala, W.A.; Weber, D.J.; HICPAC. Guideline for Disinfection and Sterilization in Healthcare Facilities, Centers for Disease Control, US; HICPAC: Atlanta, GA, USA, 2008.

2. Weinstein, R.A.; Hota, B. Contamination, disinfection, and cross-colonization: Are hospital surfaces reservoirs for nosocomial infection? Clin. Infect. Dis. 2004, 39, 1182-1189. [CrossRef] [PubMed]

3. Wolkoff, P.; Schneider, T.; Kildesø, J.; Degerth, R. Risk in cleaning: Chemical and physical exposure. Sci. Total Environ. 1998, 215, 135-156. [CrossRef]

4. Safety Data Sheet (REACH Regulation (EC) N 1907/2006). Laboratories ANIOS. Available online: https: / / media.supplychain.nhs.uk/media/documents/FAL216/COSHH/64859_FAL216\%20MSDS.pdf (accessed on 16 April 2017).

5. Ajithkumar, I.N.P.; Panneerselvam, R. Effect of Citrus hystrix and Citrus limon Extracts on Antibacterial Activity Against Human Pathogens. Available online: https:/ / www.doc-developpement-durable.org/file/ Arbres-Fruitiers/FICHES_ARBRES/combava/humanpathogensantibacterialactivityeffectofCitrushystrix\& Citruslimonextracts.pdf (accessed on 25 February 2018).

6. Madigan, M.T.; Martinko, J.M.; Brock, T.D. Brock Mikrobiologie; Pearson Deutschland GmbH: Hallbergmoos, Germany, 2009.

7. Fomites and Infection Transmission. Infection Control Today. Available online: http://www.infectioncontroltoday. com/articles/2006/11/fomites-and-infection-transmission.aspx (accessed on 20 April 2017).

8. Hardy Diagnostics Tryptic Soy Agar. Available online: https://catalog.hardydiagnostics.com/cp_prod/ Content/hugo/TrypticSoyAgar.htm (accessed on 17 April 2017).

9. A Guide to Monitoring Surface Hygiene. Orion Diagnostica. Available online: http://www.lifesignmed.com/ sites/default/ files/Hygicult\%20Guide\%20To\%20Monitoring\%20Cleanliness.pdf (accessed on 17 April 2017).

10. Chanthaphon, S.; Chanthachum, S.; Hongpattarakere, T. Antimicrobial activities of essential oils and crude extracts from tropical Citrus spp. against food-related microorganisms. Songklanakarin J. Sci. Technol. 2008, 30, 125-131.

11. Patil, J.R. Studies on Isolation and Characterization of Bioactive Compounds in Lime [Citrus aurantifolia (Christm) Swingle], Their Antioxidant and Anticancer Properties. Ph.D. Thesis, University of Agricultural Sciences, Dharwad, India, 2009.

12. Jayana, B.L.; Prasai, T.; Singh, A.; Yami, K.D. Study of antimicrobial activity of lime juice against Vibrio cholerae. Sci. World 2010, 8, 44-46. [CrossRef]

13. Jain, D.; Daima, H.K.; Kachhwaha, S.; Kothari, S.L. Synthesis of plant-mediated silver nanoparticles using papaya fruit extract and evaluation of their anti microbial activities. Dig. J. Nanomater. Biostruct. 2009, 4, 557-563.

14. Ibrahim, N.M.; Mat, I.; Lim, V.; Ahmad, R. Antioxidant activity and phenolic content of Streblus asper leaves from various drying methods. Antioxidants 2013, 2, 156-166. [CrossRef] [PubMed]

15. Gupta, C.; Garg, A.P.; Uniyal, R.C.; Gupta, S. Comparison of antimicrobial activities of clove oil \& its extract on some food borne microbes. Internet J. Microbiol. 2009, 7, 1.

16. Lim, V.; Yap, C.S.; Chong, H.W.; Shukkoor, M.S.A.; Priya, M. Antimicrobial evaluation and GC-MS analysis of Strobilanthes crispus ethanolic leaf extract. Eur. J. Med. Plants 2015, 10. [CrossRef]

17. Matlock, B.C.; Beringer, R.W.; Ash, D.L.; Allen, M.W.; Page, A.F. Analyzing Differences in Bacterial Optical Density Measurements between Spectrophotometers. ThermoFisher Scientific. Available online: https: / / pdfs.semanticscholar.org/44de/6ef94cb363c9203151d04cb63d0a9500664c.pdf (accessed on 22 April 2017).

18. Datta, A.; Ghoshdastidar, S.; Singh, M. Antimicrobial property of Piper betel leaf against clinical isolates of bacteria. Int. J. Pharm. Sci. Res. 2011, 2, 104-109.

19. Domínguez, M.C.; de la Rosa, M.; Borobio, M.V. Application of a spectrophotometric method for the determination of post-antibiotic effect and comparison with viable counts in agar. J. Antimicrob. Chemother. 2001, 47, 391-398. [CrossRef] [PubMed] 
20. RODAC Plate Procedures, Division of Comparative Medicine, University of South Florida. Available online: http:/ / www.usf.edu/research-innovation/comparative-medicine/documents/sops/s1011-rodacplate-procedures.pdf (accessed on 10 April 2017).

21. Brummer, B. Influence of possible disinfectant transfer on Staphylococcus aureus plate counts after agar contact sampling. Appl. Environ. Microbiol. 1976, 32, 80-84. [PubMed]

22. Obee, P.; Griffith, C.J.; Cooper, R.A.; Bennion, N.E. An evaluation of different methods for the recovery of meticillin-resistant Staphylococcus aureus from environmental surfaces. J. Hosp. Infect. 2007, 65, 35-41. [CrossRef] [PubMed]

23. Saad, A.H.; Gamil, S.N.; Kadhim, R.B.; Samour, R. Formulation and evaluation of herbal handwash from Matricaria chamomilla flowers extracts. Int. J. Res. Ayur Pharm. 2011, 2, 1811-1813.

24. Smith, A.C.; Hussey, M.A. Gram Stain Protocols. American Society for Microbiology. Available online: http:/ / www.asmscience.org/docserver/fulltext/education/protocol/protocol.2886.pdf?expires=1511268200\& $\mathrm{id}=\mathrm{id \& accname}=$ guest\&checksum=CF07B1FE07AC02483A954FC34DC4CC52 (accessed on 10 April 2017).

(C) 2018 by the authors. Licensee MDPI, Basel, Switzerland. This article is an open access article distributed under the terms and conditions of the Creative Commons Attribution (CC BY) license (http:/ / creativecommons.org/licenses/by/4.0/). 